\title{
Effect of heat treatment on microstructure, microhardness and corrosion resistance of ZE41 Mg alloy
}

\author{
Syam Prasad U. ${ }^{1}$, Kondaiah V. V. ${ }^{2}$, Akhil K. ${ }^{3}$, Vijay Kumar.$^{1}$, Nagamani B. ${ }^{1}$, \\ Jhansi K. ${ }^{3}$, Ravikumar Dumpala ${ }^{4}$,Venkateswarlu B. ${ }^{3}$, Ratna Sunil B. ${ }^{5}$ \\ ${ }^{1}$ Department of Mechanical Engineering, Rajiv Gandhi University of Knowledge Technologies, Nuzvid, India \\ ${ }^{2}$ Center for Design and Analysis, Department of Mechanical Engineering, CMR College of Engineering and \\ Technology, Hyderabad, India \\ ${ }^{3}$ Department of Metallurgical and Materials Engineering, Rajiv Gandhi University of Knowledge Technologies, \\ Nuzvid, India \\ ${ }^{4}$ Department of Mechanical Engineering, Visvesvaraya National Institute of Technology, Nagpur, India \\ 5 Department of Mechanical Engineering, Bapatla Engineering College, Bapatla, India \\ E-mail: bratnasunil@becbapatla.ac.in
}

\begin{abstract}
Magnesium and its alloys are now attracting a great attention as promising materials for several light weight engineering applications. ZE41 is a new Mg alloy contains Zinc, Zirconium and Rare Earth elements as the important alloying elements and is widely used in aerospace applications. In the present study, heat treatment has been carried out at two different temperatures $\left(300\right.$ and $\left.335{ }^{\circ} \mathrm{C}\right)$ to assess the effect of heat treatment on microstructure and corrosion behavior of ZE41 Mg alloy. The grain size was observed as almost similar for the unprocessed and heat treated samples. Decreased amount of secondary phase $\left(\mathrm{MgZn}_{2}\right)$ was observed after heat treating at $300{ }^{\circ} \mathrm{C}$ and increased intermetallic phase $\left(\mathrm{Mg}_{7} \mathrm{Zn}_{3}\right)$ and higher number of twins appeared for the samples heat treated at $335^{\circ} \mathrm{C}$. Microhardness measurements showed increased hardness after heat treating at $300{ }^{\circ} \mathrm{C}$ and decreased hardness after heat treating at $335^{\circ} \mathrm{C}$ which can be attributed to the presence of higher supersaturated grains after heat treating at $300{ }^{\circ} \mathrm{C}$. The samples heat treated at $335{ }^{\circ} \mathrm{C}$ exhibited better corrosion resistance compared to those of base materials and samples heat treated at $300{ }^{\circ} \mathrm{C}$. From the results, it can be understood that the selection of heat treatment temperature is crucial that depends on the requirement i.e. to improve the microhardness or at the loss of microhardness to improve the corrosion resistance of ZE41 Mg alloy.
\end{abstract}

\section{INTRODUCTION}

Magnesium $(\mathrm{Mg})$ and its alloys are light-weight nonferrous metals, now gaining importance in the materials engineering as promising alternative materials for many structural applications in the automobile, aerospace and electronic goods industries [1]. The density of $\mathrm{Mg}$ is $1.74 \mathrm{~g} \mathrm{~cm}^{-3}$, which is nearly $30 \%$ lower compared with aluminium. Additionally, high specific strength with good machinability made $\mathrm{Mg}$ as the prime choice to develop the structures for energy efficient applications [2]. It has been well understood that the microstructure of material influences the structure sensitive properties [3]. Recently, several new Mg alloys have been developed for structural and biomedical applications. $\mathrm{Mg}-\mathrm{Zn}$ group is one among the alloy family, which is widely being investigated for various strategic and critical applications. $\mathrm{ZE} 41 \mathrm{Mg}$ alloy is a new class of $\mathrm{Mg}$ alloy belongs to $\mathrm{Mg}-\mathrm{Zn}$ group which contains $\mathrm{Zn}, \mathrm{Zr}$ and rare earth (RE) elements as the alloying elements. ZE41 $\mathrm{Mg}$ alloy is used in aircraft and automobile industry [4]. If the solubility of the added alloying element in $\mathrm{Mg}$ is lower, then a secondary phase is formed which is usually observed at the grain boundaries. Additionally, the presence of $\mathrm{Zr}$ can form precipitates within the $\alpha-\mathrm{Mg}$ dendrites along with intermetallics of $\mathrm{Mg}-\mathrm{Zn}$. [5].

The volume fraction and distribution of the secondary phase are the two important key factors which influence the bulk properties of the alloy. Surya Kiran et al., [6] altered the microstructure of AZ91 Mg alloy by friction stir processing (FSP) and decreased secondary phase was observed. Due to the fine grain size and decreased intermetallic phase, improved machinability and lower edge damage was noticed during drilling operations. Recently, Venkataiah et al., [7] processed ZE41 Mg alloy by FSP and the effect of decreased grain size was found to be prominent on increasing the yield strength without decreasing ductility. On the other hand, heat treatment is a process, which combines systematic heating and cooling to alter the microstructure [8]. Swetha et al., [9] demonstrated the prominent effect of heat treatment on altering the distribution of secondary phase in AZ91 Mg alloy and further on increasing the machinability during turning. However, corrosion resistance was observed as decreased after the heat treatment due to the development of supersaturated grains. Zaho et al., [10] heat treated AZ80 Mg alloy and after solution treatment, dissolution of intermetallic phase $\left(\mathrm{Mg}_{17} \mathrm{Al}_{12}\right)$ was observed with grain coarsening effect. Further, 
increased strength and ductility was also achieved after solution and aging treatment. In $\mathrm{Mg}-\mathrm{Zn}$ alloy system, the maximum solubility of $\mathrm{Zn}$ in $\mathrm{Mg}$ at room temperature is limited to $<0.5 \mathrm{wt} . \%$. The amount of $\mathrm{Zn}$ in solid solution is progressively increased up to 2.4 wt. $\%$ at $325^{\circ} \mathrm{C}$ and stable till $340{ }^{\circ} \mathrm{C}[11,12]$. The amount of intermetallic phase that is formed between $\mathrm{Mg}-\mathrm{Zn}$ is altered at these temperatures. If the alloy is heated above $340^{\circ} \mathrm{C}$, the material reaches to a two phase region (liquid + solid solution of $\mathrm{Mg}-\mathrm{Zn}$ ). The influence of heat treatment on altering the microstructure of ZE41 and further on its corrosion behavior is not sufficiently explored yet. It is a common practice that the material is heated to a phase transformation region and is rapidly quenched to retain the corresponding microstructure [13]. In the present study, ZE41 Mg alloy has been heat treated at two different temperatures $\left(300\right.$ and $\left.335^{\circ} \mathrm{C}\right)$ just above and below the isothermal transformation temperature $\left(325{ }^{\circ} \mathrm{C}\right.$ ) as per the $\mathrm{Mg}-\mathrm{Zn}$ alloy system [11]. The influence of heat treatment on microstructure, microhardness and corrosion behavior was investigated.

\section{EXPERIMENTAL}

ZE41 Mg alloy specimens were cut from the core of a cast billet (Exclusive Magnesium, Hyderabad, India) and machined to a size of $20 \times 20 \times 5 \mathrm{~mm}$. The chemical composition of the received alloy used in the present study is shown in Table 1. Heat treatment was carried out using an electric furnace with an accuracy of $\pm 1{ }^{\circ} \mathrm{C}$ (V.B. Ceramics, Chennai, India). Initially, all the specimens were cleaned with ethanol and placed in the furnace. Heating was carried out with a rate of $5{ }^{\circ} \mathrm{C}$ per min to a temperature of $300{ }^{\circ} \mathrm{C}$ and then the specimens were kept for soaking for 4,8 and $16 \mathrm{~h}$. The soaking time was selected based on the earlier experiments [9]. Then the specimens were immersed in chilled water kept at room temperature. The specimens were coded as ZE41, 4HT300, 8HT300 and 16HT300 for unprocessed and 4,8 and $16 \mathrm{~h}$ heat treated at $300{ }^{\circ} \mathrm{C}$ respectively. Similarly, heat treatment was also done at $335^{\circ} \mathrm{C}$ and the specimens were coded as 4HT335, 8HT335 and 16HT335 respectively. The specimens were metallographically polished by using different grades of emery papers followed by diamond paste polishing. Chemical etching was done using picric acid reagent [14] and optical microscope (Leica, Germany) observations were carried out. Average grain size of the specimens was measured by linear intercept method by using Image $\mathrm{J}$ software (USA). In linear intercept method, a set of straight lines are randomly drawn on the micrograph which has been obtained at a known magnification. Then the average grain size can be obtained by dividing the total length of the line by total number of grains intercepted by the line as per ASTM standard E112-12 [15, 16]. The specimens were characterized by X-ray diffraction method (XRD, D8 Advanced, Bruker, USA) with $\mathrm{CuK} \alpha$ radiation $((\lambda=$ $=1.54 \AA$ ) between 20 and $80 \mathrm{deg}$.

Microhardness (Omnitech, India) measurements were done for all the specimens by applying $100 \mathrm{~g}$ load for $15 \mathrm{sec}$. A total of ten measurements were done on each sample by maintaining $1 \mathrm{~mm}$ distance between two consecutive indents. Electrochemical studies were carried out using $3.5 \mathrm{wt} . \% \mathrm{NaCl}$ solution as the electrolyte (IVIUM Soft, Netherlands). Potentiodynamic polarization (PDP) tests were conducted to assess the corrosion behavior of the specimens. During the experiments, a platinum rod was used as a counter electrode and a saturated calomel electrode (SCE) was used as a reference electrode with the specimen (area of $1 \mathrm{~cm}^{2}$ ) as the working electrode. All the specimens were polished using emery papers up to 2000 grade before the experiments. Open circuit potential (OCP) was established for $30 \mathrm{~min}$ and with the reference to OCP, the potential scanning range was fixed for all the specimens between $-2.5 \mathrm{~V}$ to $-1.0 \mathrm{~V}$ scan range. Potentiodynamic polarization tests were conducted at a scan rate of $5 \mathrm{mV} \mathrm{s}^{-1}$. Two measurements were done for each sample. The corrosion current density $\left(\mathrm{i}_{\text {corr }}\right)$ and corrosion potential $\left(\mathrm{E}_{\text {corr }}\right)$ values were obtained from the polarization plots using Tafel extrapolation method and average values were considered for the analysis [17]. Statistical analysis of the experimental data was done by using Origin software (USA) considering $p=0.05$ as the significant level.

\section{RESULTS AND DISCUSSION}

ZE41 Mg alloy is composed of Mg, $\mathrm{Zn}$, RE elements; additionally with smaller amounts of other trace elements such as Fe, Mn, Si and Zr. Figure 1 shows the optical microscope images of the samples. At room temperature, ZE41 Mg alloy contains $\alpha$-grains (solid solution of $\mathrm{Mg}-\mathrm{Zn}$ ) and a network of intermetallic compounds

Tab. 1. Chemical composition of ZE41 Mg alloy used in the present study

\begin{tabular}{|l|c|c|c|c|c|c|c|c|}
\hline Element (Wt. \%) & Ce & Fe & Mn & Zn & Zr & Si & TR* & Mg \\
\hline ZE41 Mg alloy & 0.56 & 0.003 & 0.01 & 3.90 & 0.56 & 0.005 & 1.10 & Balance \\
\hline
\end{tabular}

* TR = Total rare earth elements including Ce 
$\left(\mathrm{MgZn}_{2}\right)$ at the grain boundaries as indicated with white arrows in Figure 1a in addition to a smaller fraction of $\mathrm{Mg}-\mathrm{Zr}$ intermetallics [18]

It is interesting to observe from the microstructural studies that the amount of secondary phase was reduced after $4 \mathrm{~h}$ of soaking time at $300{ }^{\circ} \mathrm{C}$. The grain size was also observed as marginally decreased from a starting size of $110 \mu \mathrm{m}$ to $85 \mu \mathrm{m}$ after $4 \mathrm{~h}$ of soaking time. After $8 \mathrm{~h}$ of soaking time, the grain size was slightly increased to $105 \mu \mathrm{m}$ and further increased to $115 \mu \mathrm{m}$ after $16 \mathrm{~h}$ of soaking time respectively. However, from the statistical analysis, the difference in the average grain size was observed as marginally increased but statistically insignificant at $p=0.05$ as heat treatment time increased to $16 \mathrm{~h}$. As the soaking time was increased to 8 and $16 \mathrm{~h}$, the amount of secondary phase was observed as decreased at the grain boundaries. At $300{ }^{\circ} \mathrm{C}$, the solubility limit is increased to $2.4 \mathrm{wt} . \%$ and therefore, the reduced intermetallic phase at the grain boundaries after heat treatment suggests the formation of super saturated grains. This is similar to the formation of supersaturated grains in AZ91Mg alloy during heat treatment as reported earlier [9]. Figure 2 shows the optical microscope images of the specimens heat treated at $335{ }^{\circ} \mathrm{C}$ for 4,8 and $16 \mathrm{~h}$ of soaking time. Interestingly after heat treatment, the intermetallic phase was observed as increased at the grain boundaries compared with specimens heat treated at $300{ }^{\circ} \mathrm{C}$. Grain size of all the specimens after different soaking times was measured as close to $115 \pm 4 \mu \mathrm{m}$. No much difference in the grain size was noticed in the specimens heat treated at $335^{\circ} \mathrm{C}$. Additionally, many thermally induced twins were appeared as the heat treatment time was increased to $16 \mathrm{~h}$ as shown in Figure 3.

Figure 4 shows the XRD patterns of the samples heat treated at 300 and $335^{\circ} \mathrm{C}$. Identifying strong peaks corresponding to $\mathrm{Mg}-\mathrm{Zn}$ intermetallics is difficult as the fraction of these phases is lower. However, the peaks with lower intensities were observed and identified by comparing with the available literature $[19,20]$ before heat treatment. The corresponding intensities were observed as decreased after heat treatment at $300{ }^{\circ} \mathrm{C}$ that indicates the reduced $\mathrm{MgZn}_{2}$ phase. Whereas, peaks corresponding to $\mathrm{Mg}_{7} \mathrm{Zn}_{3}$ phase were also observed for 16HT335 sample. From the phase diagram of $\mathrm{Mg}-\mathrm{Zn}$ $[4,21]$, it could be understood that a new intermetallic

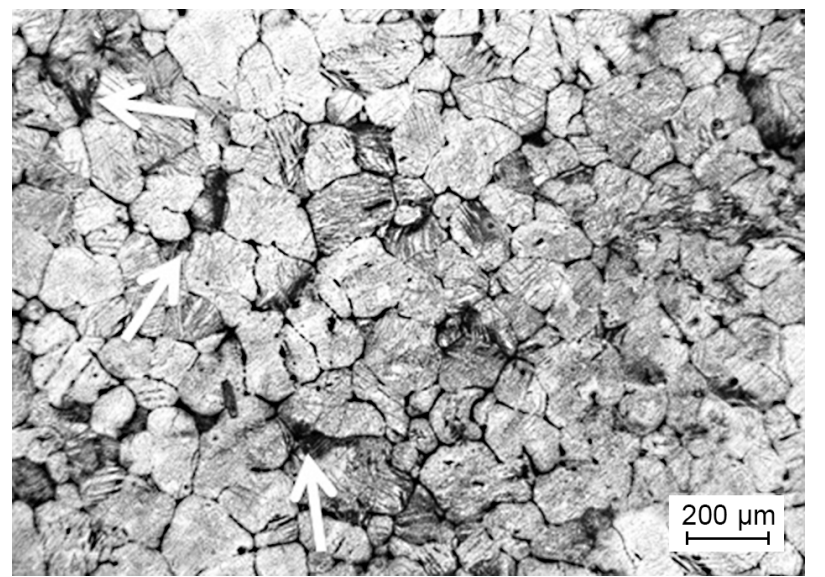

a)

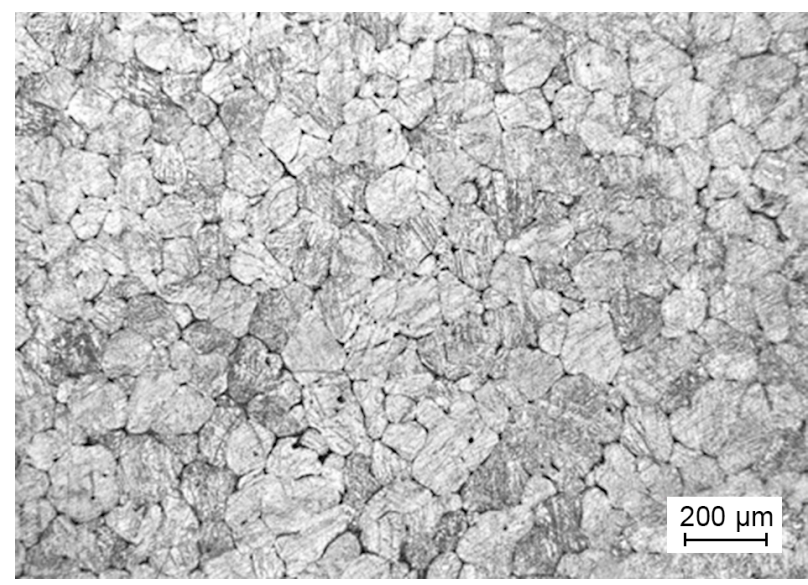

C)

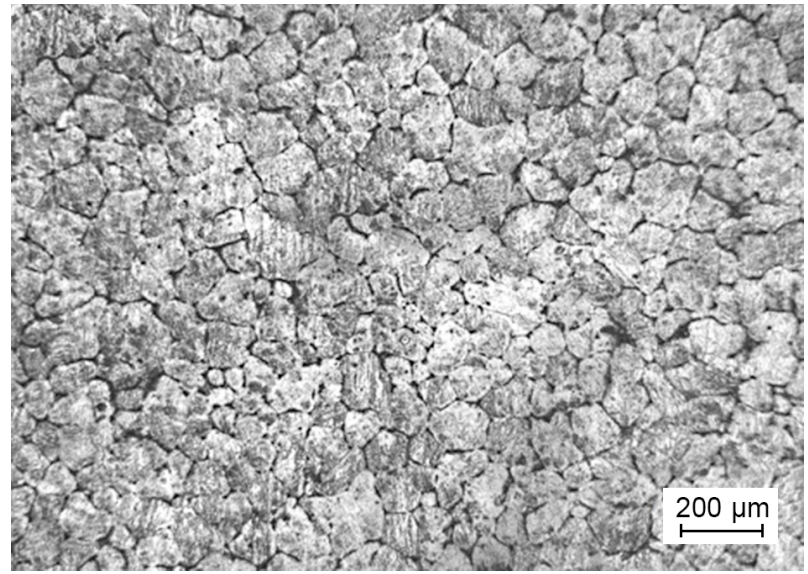

b)

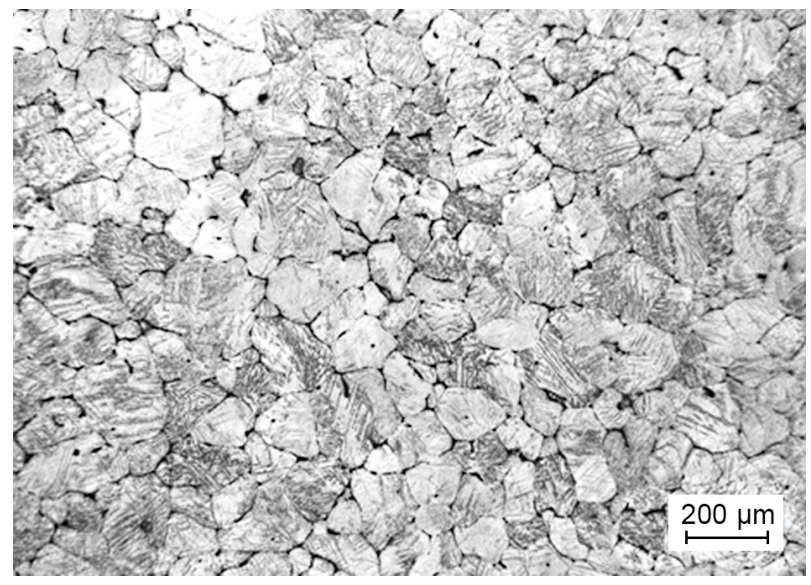

d)

Fig. 1. Optical microscopic images of the specimens: a) ZE41, b) $4 \mathrm{HT} 300$, c) $8 \mathrm{HT} 300$ and d) $16 \mathrm{HT} 300$ 
phase $\left(\mathrm{Mg}_{7} \mathrm{Zn}_{3}\right)$ is appeared if the alloy is heated above $325^{\circ} \mathrm{C}$. Therefore, in the present study, the black network like structures appeared at the grain boundaries (Fig. 2) of specimens after heat treating at $335^{\circ} \mathrm{C}$ are believed to be made of $\mathrm{Mg}_{7} \mathrm{Zn}_{3}$ phase.

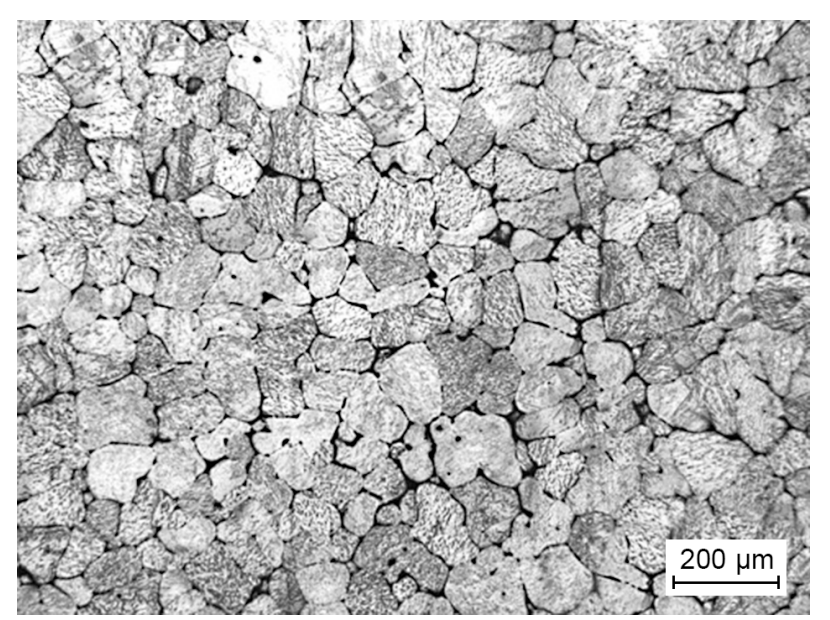

a)

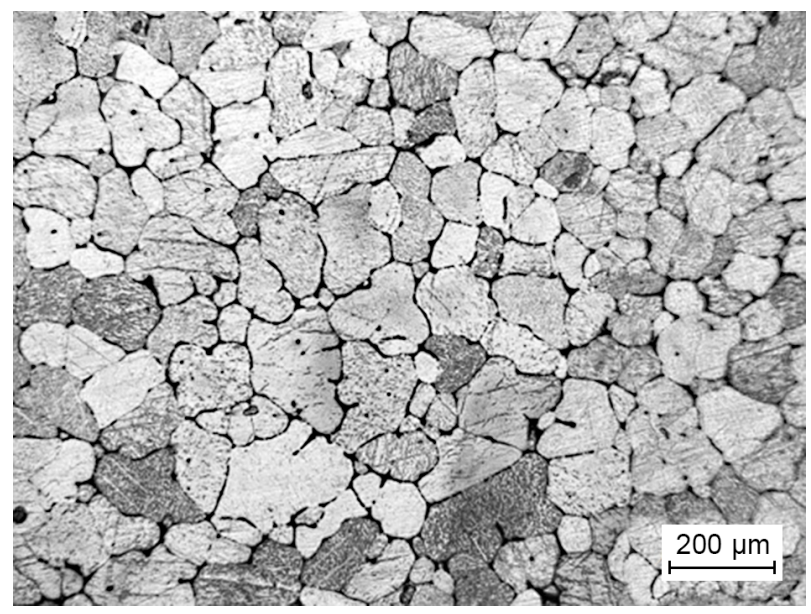

b)

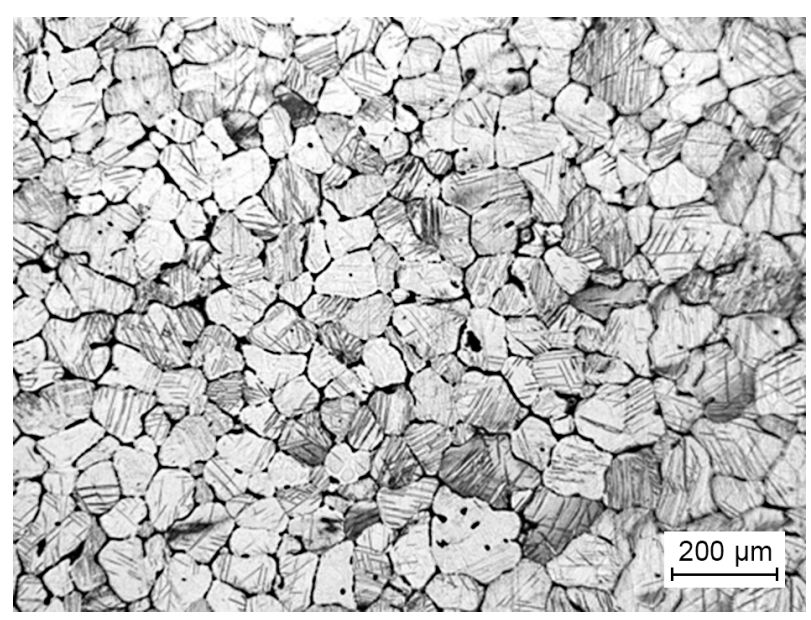

c)

Fig. 2. Optical microscopic image of the specimen heat treated at $335^{\circ} \mathrm{C}$ : a) $4 \mathrm{HT} 335$, b) $8 \mathrm{HT} 335$ and c) $16 \mathrm{HT} 335$
From the phase diagram of $\mathrm{Mg}$ and $\mathrm{Zn}[4,21]$, the relative amounts of phases can be calculated at a given temperature for a given alloy composition. By considering the temperature $300{ }^{\circ} \mathrm{C}$ on the phase diagram at 4 wt.\% $\mathrm{Zn}$, relative amounts of $\alpha-\mathrm{Mg}$ and $\mathrm{MgZn}$ intermetallic phases were calculated as $96.2 \mathrm{wt} . \%$ and

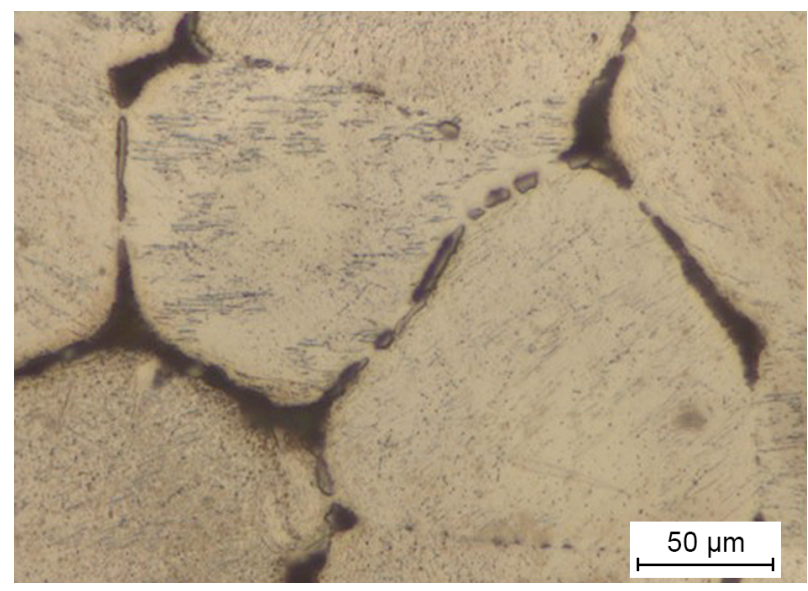

a)

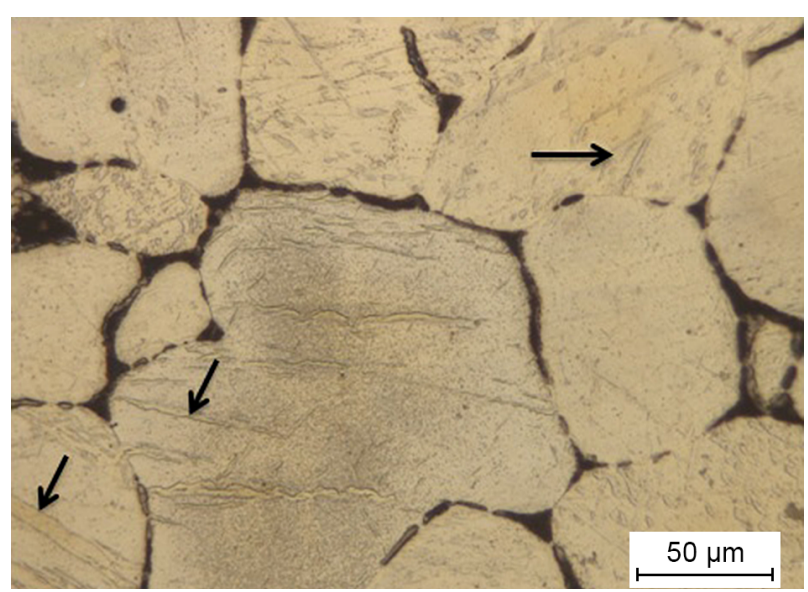

b)

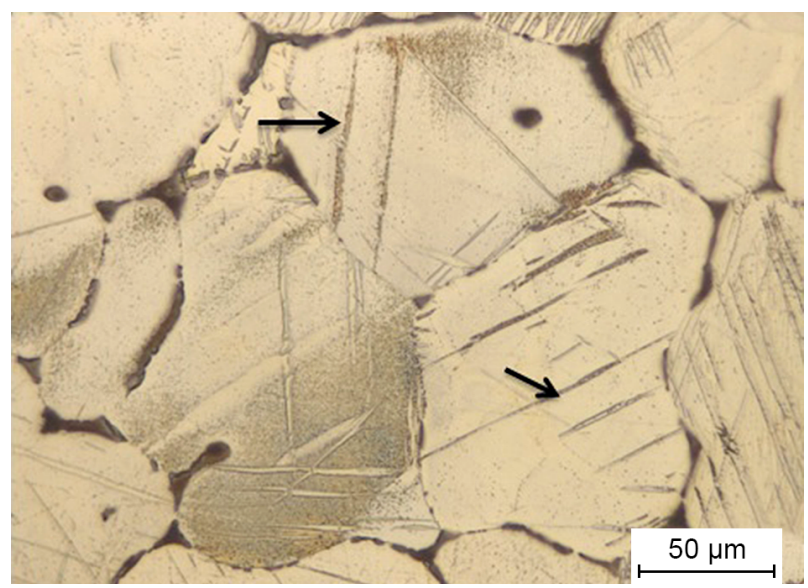

c)

Fig. 3. optical microscope images showing twin in ZE41 $\mathrm{Mg}$ alloy heat treated at $335^{\circ} \mathrm{C}$ : a) $4 \mathrm{HT} 335$, b) $8 \mathrm{HT} 335$ and c) $16 \mathrm{HT} 335$ 
3.8 wt.\% respectively. Similarly, at $335{ }^{\circ} \mathrm{C}$, the phase fractions $\left(\alpha-\mathrm{Mg}\right.$ and $\mathrm{Mg}_{7} \mathrm{Zn}_{3}$ intermetallic phase) were calculated as $93.78 \mathrm{wt} . \%$ and $6.22 \mathrm{wt} . \%$ respectively. Theoretically, from the phase diagram, higher amount of secondary phase is observed at $335^{\circ} \mathrm{C}$. Therefore, more amount of intermetallic phase $\left(\mathrm{Mg}_{7} \mathrm{Zn}_{3}\right)$ may present in the specimens heat treated at $335^{\circ} \mathrm{C}$. The change in the amount of $\mathrm{Zn}$ in the $\alpha-\mathrm{Mg}$ grains (solubility level) and altered amounts of intermetallic phase due to heat treatment, certainly influences the mechanical and corrosion behavior.

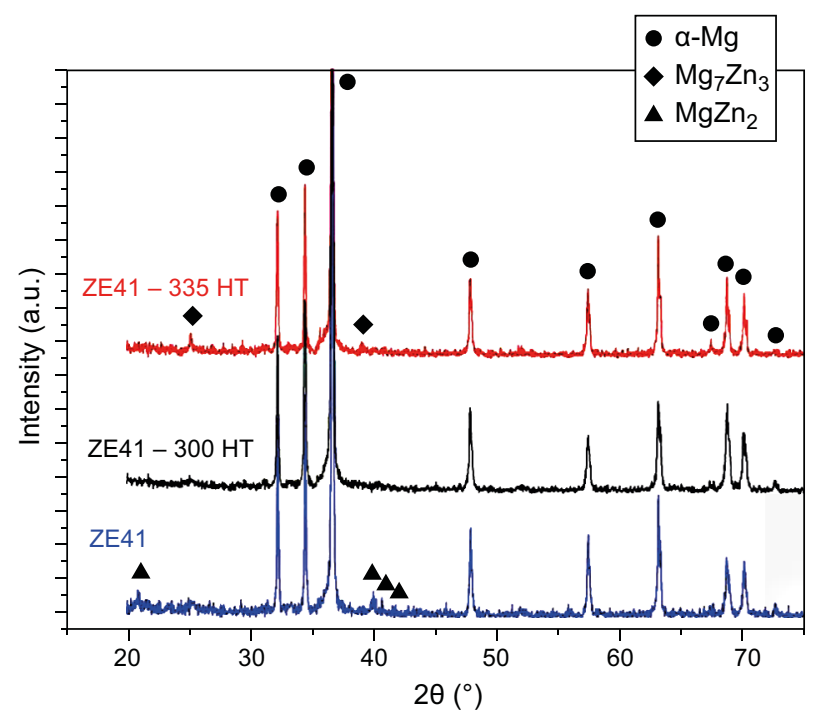

Fig. 4. XRD patterns of $16 \mathrm{~h}$ heat treated ZE41 samples at two different temperatures (300 and $\left.335^{\circ} \mathrm{C}\right)$

From the microhardness measurements as compared in Figure 5, it can be clearly seen that the hardness of the heat treated specimens was almost close to the base material $(69.5 \pm 4.2)$ after heat treatment at $300^{\circ} \mathrm{C}$. However, the specimens heat treated at $335{ }^{\circ} \mathrm{C}$ have shown a decreased hardness marginally compared with base material and also with the specimen heat treated at

Tab. 2. Electrochemical parameters of the specimen heat treated at 300 and $335^{\circ} \mathrm{C}$ compared with ZE41

\begin{tabular}{|l|c|c|}
\hline Sample & $\begin{array}{c}\text { Average corrosion } \\
\text { potential, } \mathbf{E}_{\text {corr }}(\mathbf{V})\end{array}$ & $\begin{array}{c}\text { Average corrosion } \\
\text { current density, } \\
\mathbf{i}_{\text {corr }}\left(\mathbf{m A ~ c m} \mathbf{~ c m}^{-2}\right)\end{array}$ \\
\hline ZE41 & $-1.281 \pm 0.21$ & $1.06 \pm 0.1 \times 10^{-3}$ \\
\hline 4HT300 & $-1.313 \pm 0.07$ & $2.18 \pm 0.7 \times 10^{-3}$ \\
\hline 8 HT300 & $-1.372 \pm 0.13$ & $2.03 \pm 0.6 \times 10^{-3}$ \\
\hline 16HT300 & $-1.356 \pm 0.16$ & $1.89 \pm 0.07 \times 10^{-3}$ \\
\hline 4HT335 & $-1.321 \pm 0.19$ & $0.221 \pm 0.81 \times 10^{-4}$ \\
\hline 8HT335 & $-1.279 \pm 0.11$ & $0.13 \pm 0.15 \times 10^{-3}$ \\
\hline 16HT335 & $-1.392 \pm 0.45$ & $4.56 \pm 0.13 \times 10^{-4}$ \\
\hline
\end{tabular}

$300{ }^{\circ} \mathrm{C}$. The unchanged hardness after heat treating at $300^{\circ} \mathrm{C}$ in spite of decreased intermetallic phase (MgZn) could be attributed to the formation of super saturated grains which lead to more lattice distortion compared with base material. For the specimens heat treated at $335{ }^{\circ} \mathrm{C}$, formation of new intermetallic phase led to decrease the solubility of $\mathrm{Zn}$ in $\mathrm{Mg}$ compared with the specimens heat treated at $300{ }^{\circ} \mathrm{C}$ and caused to decrease after 4 and $8 \mathrm{~h}$ of heat treatment. Interestingly, after $16 \mathrm{~h}$, both the specimens heat treated at 300 and $335^{\circ} \mathrm{C}$ have similar hardness. This can be attributed to the effect of prolonged heating that introduced thermal softening usually observed in heat treatments carried out above the recrystallization temperatures.

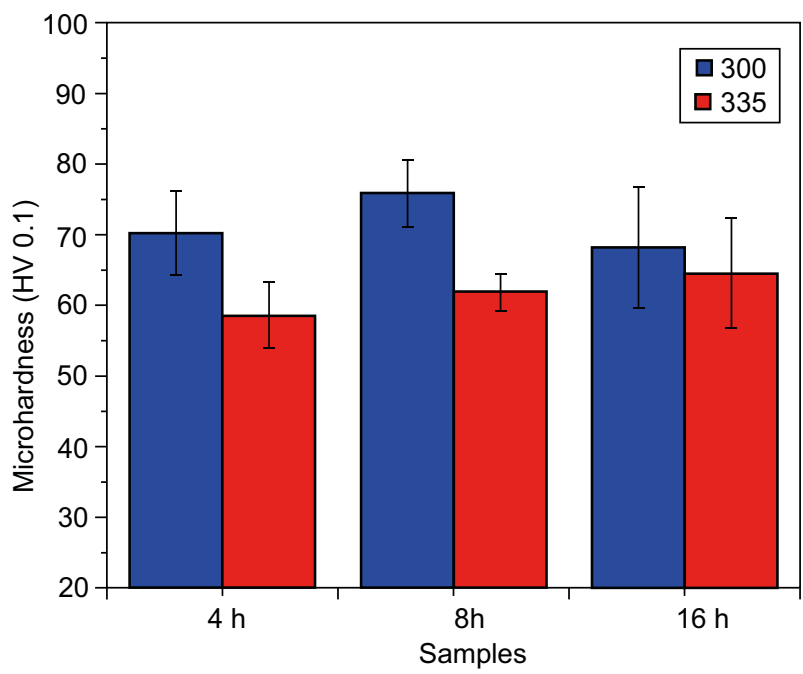

Fig. 5. Microhardness comparison of the specimens heat treated at 300 and $335^{\circ} \mathrm{C}$

Figure 6 shows typical PDP curves of all the specimens and Table 2 lists the corresponding electrochemical parameters obtained from PDP curves. From the observations, it can be noticed that the corrosion resistance was decreased as represented by increased $\mathrm{i}_{\text {corr }}$ values for specimens heat treated at $300{ }^{\circ} \mathrm{C}$ compared with ZE41. $\mathrm{E}_{\text {corr }}$ of ZE41 was observed as lower compared with all the samples. Interestingly, the corrosion resistance was increased after heat treating at $335^{\circ} \mathrm{C}$ compared with specimens heat treated at $300^{\circ} \mathrm{C}$. However, a slight variation within the $\mathrm{i}_{\text {corr }}$ values of samples heat treated at $335^{\circ} \mathrm{C}$ specimens can be noticed. This observation suggests that the super saturated grains may decrease the corrosion resistance [7] in ZE41 Mg. Presence of new intermetallics at the grain boundary may act as cathode [22] and increases the corrosion rate. At the grain boundary after heat treating at $335^{\circ} \mathrm{C}$, more amount of $\mathrm{Mg}_{7} \mathrm{Zn}_{3}$ intermetallics increases the corrosion rate. On the other hand, as reported by Neil et al., [22], dissolution of $\mathrm{Zr}$ based intermetallics during heat 


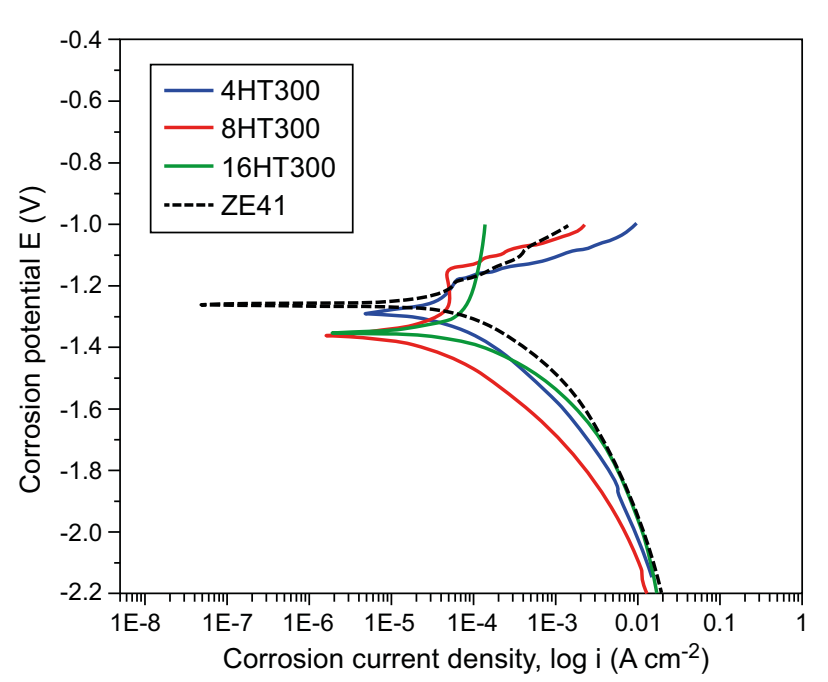

a)

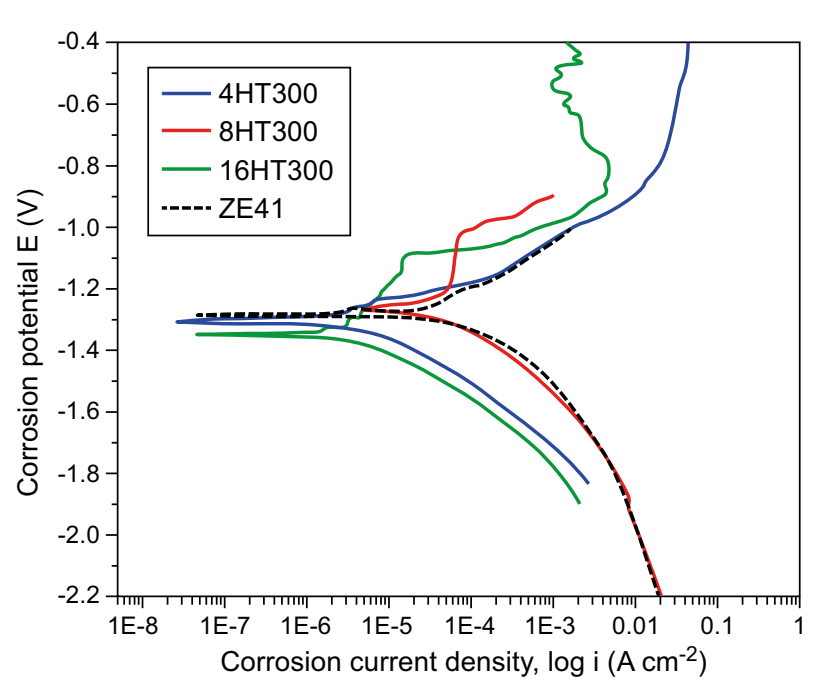

b)

Fig. 6. Comparison of the potentiodynamic polarization curves of the specimens: a) heat treated at $300{ }^{\circ} \mathrm{C}$ for different heat treatment times and $b$ ) heat treated at $335^{\circ} \mathrm{C}$ for different heat treatment times

treatment of ZE41 decreases the corrosion resistance. Interestingly, in the present work, samples treated at $335^{\circ} \mathrm{C}$ exhibited marginally lower $\mathrm{i}_{\text {corr }}$ values. From the present work, it can be understood that the heat treatment temperature is crucial in altering the microstructure of ZE41 Mg alloy which influences microhardness and corrosion behavior. Heat treatment can be done below the isothermal transformation temperature $\left(325^{\circ} \mathrm{C}\right)$, if modifying the microstructure is the prime concern with a minimal concern regarding the corrosion resistance. On contrary, if corrosion resistance is crucial by compromising the loss of hardness, heat treatment above $325^{\circ} \mathrm{C}$ is suggested. However, care must be exercised as the heat treatment temperature is close to the liquidus line of $\mathrm{Mg}-\mathrm{Zn}$ phase alloy. It is also suggested that the further investigations are needed to understand the role of supersaturated grains on corrosion behavior of ZE41 Mg alloy in addition to the type and size of intermetallics.

\section{CONCLUSIONS}

In the present study, ZE41 Mg alloy was heat treated at two different temperatures $\left(300\right.$ and $\left.335{ }^{\circ} \mathrm{C}\right)$ which fall in two different phase transformation regions of $\mathrm{Mg}-\mathrm{Zn}$ alloy system. The effect of heat treatment on altering the microstructure was studied and found that the specimens heat treated at $300{ }^{\circ} \mathrm{C}$ have lower intermetallic phase at the grain boundaries with supersaturated grains. The specimens heat treated at $335{ }^{\circ} \mathrm{C}$ have a new intermetallic phase $\left(\mathrm{Mg}_{7} \mathrm{Zn}_{3}\right)$ at the grain boundaries. Hardness was observed as slightly increased for the samples heat treated at $335{ }^{\circ} \mathrm{C}$ during 4 and $8 \mathrm{~h}$ of soaking time due to the intermetallics evolved during heat treatment but the difference was insignificant after $16 \mathrm{~h}$ of heat treatment. Corrosion behavior was observed as better for the specimens heat treated at $335^{\circ} \mathrm{C} \mathrm{com-}$ pared with the samples heat treated at $300{ }^{\circ} \mathrm{C}$. Hence from the results, it can be concluded that the heat treatment temperature plays an important role on altering the properties of ZE41 Mg alloy.

\section{Acknowledgments}

The authors would like to thank Mr. Dilip, Lab Assistant, Department of MME, RGUKT Nuzvid for helping in processing and characterization.

\section{REFERENCES}

1. Fridrich, H. E. and Mordike, B. L. Magnesium Technology, Springer, Germany, 2006.

2. Mordike, B. L. and Ebert, T. Magnesium properties applications - potential, Materials Science and Engineering A 2001, 302, 37-45.

3. Meyers, M. A.; Mishra, A.; Benson, D. J. Mechanical properties of nanocrystalline materials. Prog. Mater. Sci. 2006, 51, 427-556.

4. Polmear, I. Light Alloys: From Traditional Alloys to Nanocrystals, USA, Elsevier, 2006.

5. Avedesian, M.; Baker, H. ASM Specialty Handbook: Magnesium and Magnesium Alloys, ASM International, USA, 1999.

6. Surya Kiran, G. V. V.; Hari Krishna, K.; Sameer, SK.; Bhargavi, M.; Santosh Kumar, B,; Mohana Rao, G,; Naidubabu, Y.; Ravikumar Dumpala, Ratna Sunil, B.; 
Machining characteristics of fine grained AZ91 Mg alloy processed by friction stir processing, Trans. Nonferrous Met. Soc. China 2017, 27, 804-811.

7. Venkataiah, M.; Anup Kumar, T.; Venkata Rao, K.; Anand Kumar, S.; Siva, I.; Ratna Sunil, B.; Effect of grain refinement on corrosion rate, mechanical and machining behavior of friction stir processed ZE41 Mg alloy, Transactions of Indian Institute of Metals 2018 (in press).

8. Totten G.E. ASM Handbook Volume 4E: Heat Treating of Nonferrous Alloys, ASM International, USA, 2016.

9. Swetha Chowdary, V.; Ravikumar Dumpala, Anand Kumar, S.; Kondaiah, V. V.; Ratna Sunil, B. Influence of heat treatment on the machinability and corrosion behavior of AZ91 Mg alloy, Journal of Magnesium and Alloys 2018, $52-58$.

10. Zhao, D.; Wang, Z.; Zuo, M.; Geng, H. Effects of heat treatment on microstructure and mechanical properties of extruded AZ80 magnesium alloy, Materials and Design 2014, 56, 589-593.

11. Liu, C.; Zhu, X.; Zhou, H. Phase Diagrams for Magnesium Alloys, Central South University Press: Changsha, 2006, 35,63 .

12. Clark, J. B.; Zabdyr, L.; Moser in, Z.; Massalski, T. B.; Okamoto, H.; Subramanian, P. R.; Kacprzak , L.; (Eds.), Binary Alloy Phase Diagrams, second ed., ASM International, Materials Park, Ohio, 1990, pp. 2571-2572.

13. Predel (Ed.), B.; Phase Equilibria, Crystallographic and Thermodynamic Data of Binary Alloys, Landolt-Bornstein, Group IV, Physical Chemistry, 5 Springer- Verlag, Berlin, Germany, 1998.

14. N. Saikrishna, G. Pradeep Kumar Reddy, Balakrishnan Munirathinam, Ratna Sunil, B.; Influence of bimodal grain size distribution on the corrosion behavior of friction stir processed biodegradable AZ31 magnesium alloy, Journal of Magnesium and Alloys 2016, 4 (1), 68-76.
15. ASTM Standard E112-12. Standard test methods for determining average grain size. West Conshohocken, PA: ASTM International, 2012.

16. B. Ratna Sunil, T. S. Sampath Kumar, Uday Chakkingal, V. Nandakumar, Mukesh Doble, Nano-hydroxyapatite reinforced AZ31 magnesium alloy by friction stir processing: a solid state processing for biodegradable metal matrix composites, Journal of Materials Science: Materials in Medicine 2014, 25, 975-988.

17. Mansfeld, F.; The polarization resistance technique for measuring corrosion currents. In: Advances in Corrosion Science and Engineering Vol 6, Plenum Press, New York, 1970.

18. Neil, W.C.; Forsyth, M.; Howlett, P.C.; Hutchinson, C.R. and Hinton, B.R.W. Corrosion of magnesium alloy ZE41 - The role of microstructural features, Corrosion Science 2009, 51, 387-394.

19. Song, K.; Pan, F.; Chen, X.; Tang, A.; Pan, H. and Luo, S. Effect of $\mathrm{Zn}$ content on electromagnetic interference shielding effectiveness of $\mathrm{Mg}-\mathrm{Zn}$ alloys, Materials Research Innovations 2014, 18, S4-193-197.

20. Li, L.; Jiang, W.; Guo, P.; Yu, W.; Wang, F.; Pan, Z. Microstructure Evolution of the Mg-5.8 Zn-0.5 Zr-1.0 Yb Alloy During Homogenization, Materials Research 2017, 20 (4), 1063-1071.

21. Kevorkov, D.; Pekguleryuz, M.; Experimental study of the $\mathrm{Ce}-\mathrm{Mg}-\mathrm{Zn}$ phase diagram at $350{ }^{\circ} \mathrm{C}$ via diffusion couple techniques, Journal of Alloys and Compounds 2009, 478, 427-436.

22. Neil, W.C.; Forsyth, M.; Howlett, P.C.; Hutchinson, C.R.; Hinton, B.R.W. Corrosion of heat treated magnesium alloy ZE41, Corrosion Science 2011, 53, 3299-3308. 